\title{
A BOA-FÉ OBJETIVA ADMINISTRATIVA E A INTERPRETAÇÃO DOS CONTRATOS ADMINISTRATIVOS: A CONCRETIZAÇÃO DA FUNÇÃO PÚBLICA
}

\author{
Ricardo Pereira Lira ${ }^{1}$ \\ Roberto Correia da Silva Gomes Caldas ${ }^{2}$
}

\section{Resumo}

O presente artigo tem por objetivo analisar a aplicação do princípio da boa-fé objetiva nos contratos administrativos, em sua vertente dialógica, de modo a delimitar os efeitos e alcance de uma interpretação voltada para o cumprimento dos deveres contratuais, fincados na confiança e na lealdade. Busca, ainda, determinar em que medida podem os deveres resultantes da boa-fé objetiva ser (re)interpretados para atingir as distintas fases contratuais, inclusive quanto a aspectos que podem subjacer aos postulados das culpas in contrahendo e post factum finitum, do princípio nemo potest venire contra factum proprium e do inadimplemento contratual antecipado. A análise da boa-fé objetiva pode ser realizada também a partir da constatação da onerosidade excessiva e da lesão das obrigações contratuais, consideradas como correlatas a tal princípio, definindo assim um vetor interpretativo que resulte em desfazimento ou manutenção do contrato, conforme será examinado. Em relação à metodologia aplicada, adotou-se o método indutivo que permite estabelecer as premissas conceituais e práticas da aplicação do princípio da boa-fé objetiva no marco de uma interpretação revigorada pela concertação como fundamento estruturante da participação popular e controle social, ancorados na processualização da relação jurídica administrativa.

Palavras-chave: Boa-fé Objetiva; Deveres Contratuais; Contratos Administrativos; Função Pública; Participação Popular; Controle Social.

\section{INTRODUÇÃO}

O princípio da boa-fé tem desperto várias preocupações na doutrina e jurisprudência, principalmente a partir da previsão expressa de sua modalidade objetiva no Código Civil de 2002, a qual impõe significativas condutas no desenvolvimento das relações jurídicas, tanto de Direito Público como de Direito Privado.

E tais condutas, têm sido cada mais exigidas e observadas nas relações jurídicas contratuais de nossos dias, em que as solenidades têm dado lugar à celeridade quando do cumprimento das obrigações, o que traz ínsito também a necessidade de um espírito de colaboração e cooperação entre os contraentes.

\footnotetext{
${ }^{1}$ Professor Emérito da Universidade do Estado do Rio de Janeiro (UERJ). Professor Titular de Direito Civil (UERJ) (aposentado). Presidente Científico da Academia Brasileira de Direito Civil (ABDC).E-mail: rlira@uninet.com.br

2 Mestre e Doutor em Direito Público pela PUC/SP. Professor do curso de Mestrado da UNINOVE. E-mail: robertocsgcaldas@uol.com.br
} 
Por isso, a boa-fé objetiva impõe, em seu estudo, a verificação dos momentos de sua incidência e das funções que desempenha em cada um ao estabelecer um cumprimento das obrigações de forma colaborativa e emparceirada com a outra parte.

E para tanto, in casu ${ }_{1}$ inicia-se por uma análise da sua previsão em diversos ordenamentos jurídicos internacionais, para, em seguida, verificar-se sua positivação no ordenamento jurídico interno, em diferentes diplomas legais, extraindo-se, daí, a integral extensão legal de seu conteúdo.

Em concomitância, é trazido o aporte da doutrina e jurisprudência com a interpretação mais contemporânea dada ao referido princípio, de forma a determinar em que medida a interpretação realizada tem interferido nos contratos e sua consensualidade de modo geral, introduzindo-lhes a ideia de que os deveres de lealdade, honestidade, auxílio mútuo, cooperação e colaboração (ditos instrumentais, acessórios, ou laterais) entre as partes envolvidas em uma específica relação jurídica impõem responsabilidade e responsabilização.

E essa análise desenvolvida também perscruta a boa-fé objetiva (dita boa-fé regra de conduta) não apenas na fase de execução dos contratos, mas, igualmente, nas fases pré e pós-contratuais, dentro de uma dinâmica processual com observância da responsabilização dos envolvidos por culpas in contrahendo e post factum finitum, a implicar condutas a serem observadas segundo a tripla função desempenhada por esse princípio (de canon interpretativo-integrativo, norma de criação de deveres jurídicos instrumentais e norma de controle e limitação ao exercício de direitos subjetivos), assim, igualmente investigada (Caldas e Diz, 2015).

Em paralelo, são objeto de comento o desdobramento do princípio expresso pelo brocardo nemo potest venire contra factum proprium e a figura do inadimplemento contratual antecipado, também visto enquanto resultado da boa-fé objetiva que se deve observar nas tratativas preliminares de uma futura relação jurídica (contratual).

Além disso, por força do dever de negociação com fairness entre os contraentes em situações de lesão ou onerosidade excessiva das prestações contratuais, a boa-fé objetiva é verificada impondo a resolução judicial das avenças de execução continuada ou diferida em caso de seu inadimplemento.

$\mathrm{Na}$ subsequência do estudo, passa-se à acepção concertada e ao conceito de boa-fé objetiva administrativa, inclusive com auxílio do Direito comparado, estabelecendo seu emprego aos ajustes administrativos pátrios, a partir das lições doutrinárias e preceitos legais extraídos dos demais ramos do Direito (em específico, o Civil) quanto aos contratos em geral.

Diante de tal realidade, os princípios da boa administração pública, com sua faceta do subprincípio da eficiência, e da moralidade administrativa encontram-se intrinsecamente vinculados à noção de boa-fé objetiva administrativa, carregando para os contratos administrativos os mesmos deveres instrumentais dos contratos em geral do Direito Civil, inclusive por meio do permissivo legal existente no art. 54, caput, da Lei no 8.666/93, pondo 
em grande evidência os deveres de cooperação e colaboração não apenas em relação ao particular contratado e à Administração Pública contratante, como quanto aos reguladores institucionais e autônomos, além dos terceiros em participação popular e controle social à luz da contemporânea concepção de relação pactual administrativa concertada.

A partir dessas observações, tem-se que a boa-fé objetiva administrativa é considerada inclusive como um vetor interpretativo integrador da "vontade pública" - função legalmente estipulada - para atendimento da dimensão consensual das cláusulas expressas (como as regulamentares) e, principalmente, implícitas (ditas exorbitantes) nos ajustes públicos, aspecto que é verificado em conjunto com a outra diretriz hermenêutica, a causa, cuja teoria é igualmente empregue no exame de suas fases.

Pari passu, a função controladora e limitadora pode representar um aspecto restritivo relativo ao exercício abusivo - tanto de direitos subjetivo como de prerrogativas administrativas - bem como a introdução dos deveres instrumentais, inclusive implícitos, aos contratos administrativos, em si, implica um fator de balizamento às ditas cláusulas exorbitantes (em regra também implícitas) pelo viés da chamada relação jurídica de Administração Pública (com suas processualização da relação e concertação) e da moralidade administrativa, cuja boa-fé objetiva administrativa ressai como expressão direta na relação jurídica administrativa concretamente considerada.

Dessa maneira, o estudo assim desenvolvido busca analisar os principais aspectos da boa-fé objetiva, tanto em âmbito civil como administrativo, extraindo, ao final, suas conclusões para uma conceituação mais adequada às suas funções desempenhadas nas relações jurídicas de natureza administrativa, com seu contexto processual e concertado, e segundo as orientações jurisprudenciais dos Tribunais nacionais.

Tal estudo justifica-se pela necessidade de adequar a interpretação dada às relações jurídicas pactuais públicas às premissas já estabelecidas pela aplicação da boa-fé objetiva como elemento a guiar a conduta das partes contratantes, ainda que uma delas tenha natureza pública - o que se infere nos contratos administrativos de forma geral.

Em relação ao aspecto metodológico, centrou-se nos aspectos principais estabelecidos para uma pesquisa teórica que envolve temas de Direito Administrativo e de Direito Civil, devido especialmente ao caráter específico e singular que deve estar presente em toda análise calcada na aplicação de institutos específicos mas que se interrelacionam de modo a alcançar um objetivo comum, qual seja, a consideração da boa-fé objetiva a empregarse na interpretação do contrato administrativo em sua vertente consensuada e exteriorizadora da função pública. Neste sentido, devem-se utilizar métodos que permitam analisar a evolução e desenvolvimento do princípio da boa-fé objetiva, a formação do contrato administrativo e seus requisitos, e a formulação da participação popular e controle social neles adotados. O método indutivo, in casu, permite estabelecer as premissas conceituais e práticas 
aplicadas ao tema da relação jurídico-administrativa no marco de uma interpretação revigorada pela concertação como fundamento estruturante da participação popular e controle social, ancorado no princípio da boa-fé objetiva.

\section{A PREVISÃO NORMATIVA DA BOA-FÉ OBJETIVA NO DIREITO POSITIVO COMPARADO E SUA ACEPÇÃO}

É de valia inquestionável tecer algumas considerações doutrinárias, mencionar dispositivos legais, seja dos códigos civis estrangeiros, e do Código Civil brasileiro de 2002, e dados jurisprudenciais, referentes ao novo Direito Contratual, que terminou por se consolidar em nosso ordenamento jurídico. E no âmago desse novo Direito Contratual, está o princípio da boa-fé objetiva.

Nesse diapasão, embora seja, em regra, redundante a citação expressa de disposições legais em estudos jurídico-científicos, no caso em tela isso se revela, a contrario sensu, de suma relevância, pois do cotejo das distintas redações coligidas do Direito estrangeiro e pátrio permite extrair-se um contexto mais robusto das várias facetas desse princípio em exame, tal qual albergadas pelas diferentes sociedades em seus ordenamentos jurídicos, de sorte a ter-se sua acepção em sentido mais lato e, com isso, completo.

No direito estrangeiro, o princípio da boa-fé objetiva já estava reconhecido em vários Códigos Civis.

O Código Civil alemão (BGB), no $\$ 242$, de 1896, estatui que "o devedor é obrigado a cumprir a sua obrigação de boa-fé, atendendo às exigências dos usos do tráfico jurídico"3.

O Código Civil italiano de 1942, em seu art. 1175, preceitua que "O devedor e o credor devem comportar-se segundo as regras de equidade (Cod. Civ. 1337, 1358)”4. O seu art. 1337 dispõe que "As partes, na condução das negociações e da formação do contrato, devem comportar-se segundo boa-fé (1366,1375, 2208)" E o subsequente art. 1366 estabelece que “ $O$ contrato deve ser interpretado segundo boa-fé $(1337,1371,1375)$ ”.

O Código Civil da Espanha, artígo 7.1 dispõe que "Os direitos deverão exercitar-se conforme as exigências da boa-fé". No artigo 1258 declara que "Os contratos se aperfeiçoam pelo mero consentimento, e

\footnotetext{
${ }^{3} \$ 242$. Leistung nach Treu und Glauben. Der Schuldner ist verpflichtet, die Leistung so zu bewirken, wie Treu und Glauben mit Rücksicht auf die Verkehrssitte es erfordern.

${ }^{4}$ Art. 1175 Comportamento secondo correttezza Il debitore e il creditore devono comportarsi secondo le regole della correttezza (Cod. Civ. 1337, 1358).

${ }^{5}$ Art. 1337 Trattative e responsabilità precontrattuale Le parti, nello svolgimento delle trattative e nella formazione del contratto, devono comportarsi secondo buona fede (1366,1375, 2208).

${ }^{6}$ Art. 1366 Interpretazione di buona fede Il contratto deve essere interpretato secondo buona fede $(1337,1371,1375)$.

${ }^{7}$ Artículo 7 1. Los derechos deberán ejercitarse conforme a las exigencias de la buena fe. vol. 08, nº. 04, Número Especial. Rio de Janeiro, 2015.pp. 2670-2695 
desse momento obrigam, não apenas ao cumprimento do que expressamente pactuado, senão também a todas às consequências que, segundo sua natureza, estejam de acordo com a boa-fé, ao uso e à lei”"

O Código Civil português, artigo $762^{\circ}$ (Princípio geral), prescreve que: "1. O devedor cumpre a obrigação quando realiza a prestação a que está vinculado. 2. No cumprimento da obrigação, assim como no exercício do direito correspondente, devem as partes proceder de boa-fé".

O Código Civil francês, de 1804, estabelece: "As convenções legalmente constituídas têm o mesmo valor que a lei relativamente às partes que as fizeram. Só podem ser revogadas pelo seu consentimento mútuo, ou pelas causas que a lei admite. Devem ser executadas de boa-fé" (art. 1134)9.

O Código Civil suíço determina: "Art. 2 (B. Conteúdo das relações jurídicas; I. Procedimento de acordo com a boa-fé) Todos têm, no exercício de seus direitos e na execução de suas obrigações, de agir de acordo com a boa-fé. O abuso evidente de um direito não encontra proteção legal" ${ }^{\prime 10}$.

Com base em tais disposições, é possível se extrair uma acepção de boa-fé objetiva que compreende o princípio da boa-fé em negociações preliminares, na formação do contrato, durante a existência da relação jurídica obrigacional e após seu exaurimento, segundo os usos e costumes incorporados ao ordenamento da sociedade em referência e mediante um comportamento dos envolvidos com equidade, além de orientar toda a interpretação contratual.

\section{DIREITO POSITIVO PÁTRIO E SUA CRÍTICA DOUTRINÁRIA}

No direito brasileiro, o Código Comercial de 1850 aludia à boa-fé como vetor de interpretação das avenças mercantis (art. 131). A regra, porém, ficou no esquecimento.

O Código Civil de 1916 - ressalvado o art. 1.443 cuidando do dever da boa-fé nos contratos de seguro não se referia ao princípio da boa-fé objetiva, disciplinando apenas a boa-fé subjetiva em matéria de posse, e no caso do casamento putativo. Ainda assim a doutrina e a jurisprudência, por vezes, a ele recorriam.

Vale lembrar que Gomes (1972, p. 171) considerava o princípio da boa-fé como "norma em branco", listando três perigos que a ausência de boa-fé acarretariam:

1. A frivolidade na interpretação;

2. A insegurança no comércio jurídico; e

\footnotetext{
${ }^{8}$ Artículo 1258 Los contratos se perfeccionan por el mero consentimiento, y desde entonces obligan, no solo al cumplimiento de lo expresamente pactado, sino también a todas las consecuencias que, según su naturaleza, sean conformes a la buena fe, al uso y a la ley.

${ }^{9}$ Art. 1134. Les conventions légalement formées tiennent lieu de loi à ceux qui les ont faites. Elles ne peuvent être révoquées que de leur consentement mutuel, ou pour les causes que la loi autorise. Elles doivent être exécutées de bonne foi.

${ }^{10}$ Art. 2 (B. Inhalt der Rechtsverhältnisse I. Handeln nach Treu und Glauben) 1 Jedermann hat in der Ausübung seiner Rechte und in der Erfüllung seiner Pflichten nach Treu und Glauben zu handeln. 2 Der offenbare Missbrauch eines Rechtes findet keinen Rechtsschutz.
} 
3. O arbítrio na interpretação.

Importa igualmente recordar que o Anteprojeto de Código de Obrigações, elaborado por Orozimbo Nonato, Philadelpho Azevedo e Hahnemann Guimarães (1943), dispunha no art. 66 que "as declarações devem ser interpretadas conforme a boa-fé e os usos e costumes dos negócios".

Com o advento do Código de Defesa do Consumidor (Lei 8.078, de 11 de setembro de 1990), verificou-se a primeira positivação consequente e eficaz do princípio da boa-fé. No art. 51, IV, o estatuto consumerista estabelece que:

São nulas de pleno direito, entre outras, as cláusulas contratuais relativas ao fornecimento de serviços e produtos que... IV - estabeleçam obrigações consideradas iníquas, abusivas, que coloquem o consumidor em desvantagem exagerada, ou sejam incompatíveis com a boa-fé ou a equidade.

Observam Tepedino e Schreiber (2005, p. 32) que a referência dessa norma

Não é a uma boa-fé subjetiva, como estado de consciência do fornecedor ou do consumidor, mas a uma nova concepção de boa-fé, que, desvinculada das intenções íntimas do sujeito, vem exigir comportamentos adequados ao parâmetro de lealdade, honestidade e colaboração no alcance dos fins perseguidos em cada relação obrigacional.

A consagração do princípio da boa-fé objetiva tal e como estipulado no Código de Defesa do Consumidor, referem-se às situações jurídicas não paritárias, ou seja, aquelas em que esteja presente uma parte hipossuficiente, o consumidor.

O Código Civil de 2002 veio explicitar a necessidade da boa-fé nos negócios jurídicos em geral, paritários ou não, isto é, mais especificamente nos contratos em geral, seja a boa-fé considerada na sua função interpretativa, seja na celebração ou na execução do contrato.

O art. 113 desse diploma legal determina que "os negócios jurídicos devem ser interpretados conforme a boa-fé e os usos do lugar de sua celebração". O art. 187, a seu turno, estatui que "também comete ato ilícito o titular de um direito que, ao exercê-lo, excede manifestamente os limites impostos pelo seu fim econômico ou social, pela boa-fé ou pelos costumes". E o art. 422 estabelece que "os contratantes são obrigados a guardar, assim na conclusão do contrato, como em sua execução, os princípios de probidade e de boa-fé".

A boa-fé, o comportamento probo e correto das partes, cabe ressaltar, hão de ser exigidos não só na celebração do contrato e na sua execução, mas também nas tratativas, nas negociações preliminares.

Permita-se a transcrição de um trabalho de Fichtner Pereira (2001, pp. 87-89) que, embora longa, é deveras relevante.

As negociações contratuais.... não fazem surgir para as partes nelas envolvidas relação jurídica de natureza obrigacional, já que não se encontra ainda formado o vínculo jurídico que obrigará uma delas, ou ambas, a realizar uma prestação em favor da outra.

O fato, no entanto, de duas pessoas estarem interagindo com vistas à formação de uma relação contratual, ou seja, objetivando uma finalidade comum, modifica substancialmente a natureza da relação que travam em sociedade. 
O dever de não causar injustamente danos a outrem é reconhecido como dever jurídico genérico, que alcança todas as pessoas, em todas as situações. Esse dever jurídico genérico... tem caráter negativo.

Quando duas pessoas se relacionam com vistas à formação de uma relação jurídica contratual, ultrapassam esse estágio do relacionamento humano em sociedade, cujo dever jurídico consiste apenas em não prejudicar injustamente.

A circunstância de as partes estarem negociando com vistas à formação do contrato faz com que surjam outros deveres, além do dever genérico de não causar dano injusto a terceiros. Os deveres que surgem com o início das negociações contratuais têm feição positiva e se aproximam mais dos deveres que são típicos das relações contratuais, do que dos que tipificam meras normas de conduta em sociedade.

Os deveres que surgem com o início das negociações contratuais decorrem, todos, da incidência do princípio da boa-fé. Não se encontrará quem conteste o fato de que quem negocia com vistas à formação de uma relação contratual deve agir de boa-fé.

Reconhecida a incidência do princípio da boa-fé na fase das negociações contratuais, é preciso se fixar que tipo de boa-fé será exigido das partes, se a boa-fé subjetiva ou a boa-fé objetiva.

A boa-fé objetiva...é característica das relações contratuais, em razão de conter deveres positivos de conduta, todos derivados da necessidade de as partes cooperarem entre si para alcançarem as finalidades projetadas no contrato.

Prossegue o autor citado:

É intuitivo que as mesmas exigências de conduta, típicas das relações contratuais, que fazem surgir os chamados típicos deveres instrumentais ou secundários, devem ser estendidas à fase pré-contratual, quando estão as partes trocando informações e deliberando sobre constituírem ou não a relação contratual.

Os deveres jurídicos instrumentais ou secundários são reconhecidos ao lado do dever jurídico principal, consistente na obrigação de realizar a prestação em favor da outra parte.

$\mathrm{Na}$ fase pré-contratual, contudo, os deveres jurídicos decorrentes da incidência do princípio da boa-fé não terão caráter acessório de um dever jurídico principal, já que esse dever jurídico principal ainda não existe. Nessa fase, esses deveres jurídicos assumirão o papel principal na regulação do comportamento das partes, pois serão eles que definirão as exigências de conduta de uma parte em relação à outra.

As regras, portanto, que determinam se a conduta das partes contratuais na fase das negociações contratuais produz consequências jurídicas são as que integram o princípio da boa-fé (Fitchner Pereira, 2001, p. 89) (grifo nosso).

Uma das críticas que Junqueira Azevedo (2000) faz ao Código Civil vigente foi exatamente a de não se prever, no art. 422, expressamente a exigência da boa-fé nas negociações preliminares.

Contudo a ordem natural das coisas, bem como a sólida argumentação de Fichtner Pereira no entrecho acima transcrito, deixam ver que a boa-fé é uma necessidade exigida e impostergável nas negociações contratuais. Aliás, o princípio da boa-fé deve estar presente não só no momento pré-contratual, como igualmente na fase posterior ao adimplemento, como imposição da culpa post factum finitum (Negreiros, 2006).

Como observa Garcia da Fonseca (2007, p. 127) “(...) Além de ganhar relevo que antes não tinha, a boafé também se transmuda de subjetiva em objetiva, e passa a reger com firmeza todas as fases do contrato, antes, durante e depois de sua execução”. 


\section{EXTENSÃO DO SIGNIFICADO DE BOA-FÉ OBJETIVA E DEVERES INSTRUMENTAIS}

Anotava Gomes (1991), escrevendo ao tempo da vigência do Código Civil de 1916, que o princípio da boa-fé objetiva vincula-se não só com a interpretação do contrato, mas também com o interesse social de segurança das relações jurídicas, devendo as partes, como está expresso no BGB, "...agir com lealdade e confiança recíprocas" (Gomes, 1991, p. 43). Em uma palavra, dizia Gomes (1991, p. 43), "...devem proceder com boa-fé”, significando que "...entre o credor e o devedor é necessária a colaboração, um ajudando o outro na execução do contrato".

Para Lima Marques (1999, p. 106-107) a definição de boa-fé objetiva pode ser entendida como

Uma atuação "refletida", uma atuação refletindo, pensando no outro, no parceiro contratual, respeitando-o, respeitando seus interesses legítimos, suas expectativas razoáveis, seus direitos, agindo com lealdade, sem abuso, sem obstrução, sem causar lesão ou desvantagem excessiva, cooperando para atingir o bom fim das obrigações: o cumprimento do objetivo contratual e a realização dos interesses das partes.

Nesse sentido, resume Ferreira da Silva (2002, p. 270)

A boa-fé expande as fontes dos deveres obrigacionais, posicionando-se ao lado da vontade e dotando a obrigação de deveres orientados a interesses distintos dos vinculados estritamente à prestação, tais como o não-surgimento de danos decorrentes da prestação realizada ou a realização do melhor adimplemento.

Como consequência, amplia-se o suporte fático do inadimplemento obrigacional, considerando-se violação do contrato o descumprimento de deveres laterais ou acessórios, a dar lugar, não apenas à pretensão ressarcitória, mas, igualmente, àqueles outros remédios resultantes do inadimplemento: a possibilidade de recusar a prestação com base na exceção do contrato não cumprido e, no limite, a faculdade de resolver o contrato (Código Civil, artigos 475 e 476).

A concepção da "obrigação como processo", difundida entre nós por Couto e Silva (1976), tem aí uma de suas expressões mais emblemáticas: o valor dogmático da relação obrigacional complexa está em demonstrar a importância dos deveres laterais na consecução dos "interesses globais visados pela relação obrigacional complexiva" (Alarcão, 1983, p. 56).

Os deveres instrumentais, anexos, existentes ao lado da prestação principal componente do vínculo obrigacional, informam a correção do comportamento dos contratantes (ou das partes) na fase de negociações, tendo em vista que essas situações pré-contratual, contratual e pós-contratual devem ser dominadas por um espírito de cooperação, exigindo-se de ambas as partes que atuem em favor da consecução e realização útil da prestação principal, atendidas as necessidades e expectativas do credor.

Em artigo científico, Tepedino (2015, p. 48) assevera que:

Ao lado desse duplo aspecto, a boa-fé constitui-se ainda em fonte criadora de deveres anexos à prestação principal, ao lado dos deveres específicos estabelecidos no instrumento 
contratual. Trata-se dos deveres de lealdade, de honestidade, de transparência e de informação, dentre outros exigidos dos contratantes de acordo com as peculiaridades de cada regulamento contratual, no sentido de otimizar o desempenho das prestações da contraparte. Tal função da boa-fé objetiva, embora menos aparente no Código Civil, pode ser, em conformidade com a melhor doutrina e à semelhança da interpretação atribuída ao $\$ 242$ do BGB, deduzida do já transcrito artigo 422 do diploma brasileiro.

Tudo isso corresponde a uma nova visão da obrigação, entendida dinamicamente como um processo, tendo em mira a finalidade global, e não apenas o adimplemento formal, que nem sempre significa uma entrega útil da prestação (Couto e Silva, 1976, passim).

São deveres instrumentais o dever de informação, o dever de lealdade e correção, o dever de proteção e cuidado com a contraparte, e, finalmente, o dever de segredo ou sigilo.

Cordeiro (2007) divide tais deveres acessórios em deveres de lealdade, deveres de proteção e deveres de esclarecimento ou informação.Já Martins-Costa (1999) enumera esses deveres, a saber:

1. Deveres de cuidado, previdência e segurança;

2. Deveres de aviso e esclarecimento;

3. Deveres de informação;

4. Dever de prestar contas;

5. Deveres de proteção e cuidado com a pessoa e o patrimônio da contraparte;

6. Deveres de omissão e segredo.

Aludindo ao direito alemão Ebke e Steinhauer (1997) listam cinco categorias do que chamam de "direitos acessórios":

1. Dever de cuidado com a outra parte (sua vida, segurança ou patrimônio);

2. Dever de negociar com fairness;

3. Dever de abster-se de qualquer coisa que possa comprometer o propósito do contrato;

4. Dever de assistir a outra parte de modo a que o contrato possa prosperar; e

5. Dever de uma parte revelar fatos à outra.

Todos esses deveres são uma decorrência do princípio da boa-fé objetiva.

\section{FUNÇÕES DA BOA-FÉ OBJETIVA}

Nesse contexto, postos a extensão do significado de boa-fé objetiva e seus deveres instrumentais, calha tecerem-se observações sobre as funções do princípio da boa-fé objetiva, as quais podem ser definidas sob um tríplice aspecto:

1. Canon interpretativo-integrativo;

2. Norma de criação de deveres jurídicos instrumentais; e 
3. Norma de controle e limitação ao exercício de direitos subjetivos.

Essa tripartição funcional foi sugerida modernamente por Wieacker (1997), repercutindo intensamente na doutrina nacional, como se verifica nas obras de Martins-Costa (1999), Aguiar Júnior (1995) e Silva (1996). Ainda, conforme leciona Negreiros (2006) essas funções se complementam e podem incidir sobre cada caso concreto conjuntamente.

Como regra de interpretação, o princípio da boa-fé objetiva serve para melhor especificar a finalidade da avença à luz das circunstâncias concretas que a caracterizam. Neste sentido, como parâmetro de interpretação do contrato, a boa-fé objetiva atua como "(...) mandamento imposto ao juiz de não permitir que o contrato, como regulação objetiva, dotada de um específico sentido, atinja finalidade oposta ou contrária àquela que, razoavelmente, à vista do seu escopo econômico-social, seria lícito esperar" (Martins-Costa, 2006, p. 432). Ainda no mesmo sentido, manifesta-se Tepedino, Barboza e Moraes (2004).

Como norma de criação de deveres jurídicos, a boa-fé dá origem aos chamados "deveres laterais", também conhecidos como acessórios ou ainda secundários, em razão de não se referirem direta e primordialmente ao objeto central da obrigação. Ao exigir que os contratantes, quer na conclusão, quer na própria execução do contrato, "guardem os princípios da probidade e da boa-fé", o Código Civil, mais do que apenas determinar um dever geral de não prejudicar (alterum non laedere) autoriza a imposição de uma série de deveres de conduta mutuamente exigíveis entre os contratantes e que independem da vontade de um ou de outro.

Já se referiu alhures que Martins Costa (2006) enumera cinco categorias para esses deveres acessórios ou laterais, sendo que, permita-se recordar, a autora ressalta os deveres de colaboração e cooperação, como o de colaborar para o correto e útil adimplemento da obrigação principal.

Cuida-se, em suma, de deveres de proteção e de cooperação, que não se podem tipificar por meio de catálogos abstratos e apriorísticos. É que, para a especificação desses deveres, a natureza do vínculo contratual, em maior ou menor medida fundada na confiança, a condição econômica das partes, mais ou menos discrepante, serão da maior relevância.

No que toca à terceira função, o princípio da boa-fé ajusta-se à teoria do abuso de direito, para criar restrições e limites ao exercício dos direitos subjetivos. Nesse passo, a boa-fé funciona como parâmetro de valorização do comportamento dos contratantes, com a finalidade de proscrever aqueles exercícios considerados arbitrários e irregulares. Nesses casos se o comportamento de uma das partes não resistir à avaliação de sua conformidade com a boa-fé, não poderá socorrer-se da tutela do ordenamento jurídico (Tepedino; Barboza; Moraes, 2004). 


\section{REPERCUSSÕES DA BOA-FÉ OBJETIVA COMO LIMITADORA DO EXERCÍCIO DE DIREITOS SUBJETIVOS}

São repercussões imediatas do princípio da boa-fé objetiva, em sua função controladora e impositiva de restrições e limites ao exercício dos direitos subjetivos, o subprincípio segundo o qual nemo potest venire contra factum proprium (visto como a faceta ética, psicológica e social da regra "pacta sunt servanda" (Cordeiro, 2007, p. 751), em atenção à necessária confiança recíproca (Wieacker, 1997), com vinculação direta ao primado constitucional da solidariedade social (Schreiber, 2005) e a figura que consubstancia o inadimplemento contratual antecipado ( tu quoque, com sua maior expressão, a exceptio non adimpleti contractus - art. 476, do CC de 2002), ambos havidos como decorrências, desdobramentos da teoria dos atos próprios. Vejamos cada qual deles.

Por força do nemo potest venire contra factum proprium, a ninguém é dado comportar-se contra o próprio ato. Em sua configuração contemporânea, este princípio, ou subprincípio, quando seja considerado um desdobramento do princípio maior da boa-fé objetiva, veda que alguém tenha uma conduta em contradição com seu comportamento anterior, lesando a confiança de quem acreditara na preservação do comportamento inicial.

Como anota Schreiber (2005, p. 95):

De fato a proibição de comportamento contraditório não tem por fim a manutenção da coerência por si só, mas afigura-se razoável apenas quando e na medida em que a incoerência, a contradição aos próprios atos, possa violar expectativas despertadas em outrem e assim causar-lhe prejuízo.

Segundo esse autor, os pressupostos que ensejam a aplicação da figura do nemo venire contra factum proprium são os seguintes:

1. Um factum proprium, ou seja, uma conduta inicial;

2. A legítima confiança de outrem na conservação do sentido objetivo dessa conduta;

3. Um comportamento contraditório com este sentido objetivo (e, por isso mesmo, violador da legítima confiança); e

4. Um dano, ou, no mínimo, um potencial de dano a partir da contradição (Schreiber, 2005).

Outro reflexo do princípio da boa-fé objetiva é a figura do inadimplemento contratual antecipado (Neves, 2009). A abordagem doutrinária do adimplemento contratual não se limita mais ao ato pontual do devedor entregando ao credor a prestação esperada. O fenômeno obrigacional nos dias de hoje obedece a uma perspectiva não apenas estática, mas sobretudo dinâmica, nas suas sucessivas etapas de nascimento, prestação e adimplemento útil ao credor.

A concepção da relação jurídica obrigacional como o encadeamento, em forma processual, dos atos que tendem ao cumprimento do dever implica o reconhecimento de que o comportamento das partes, antes e depois 
da entrega da prestação principal, passa a produzir efeitos jurídicos diferenciados, que podem superar, em importância, aqueles que resultem do cumprimento, em si, da prestação principal.

Foca-se a relevância dos chamados deveres laterais ou acessórios, que são importantes em sua observância, para que o adimplemento da prestação principal seja verdadeiramente proveitoso para o credor, como ele esperava quando da celebração do negócio jurídico.

Diz-se, então, que às partes incumbe zelar pela utilidade da prestação, antes, durante e depois da sua entrega. Não só por ter expressamente declarado que não irá cumprir a obrigação contratada, ou quando isso resulte claro da sua conduta não cumprindo os chamados deveres laterais, tais situações ensejam ao credor ter a conviç̧ão do inadimplemento contratual antecipado, autorizando-lhe a ingressar em juízo e pleitear o cumprimento exato da prestação principal, ou buscar a rescisão do vínculo contratual, com condenação da contraparte em perdas e danos.

Essa entre nós é uma solução perfeitamente admitida, por influência do sistema da common law, que consagra a doutrina anglo-saxã do antecipated breach of contract. É um exemplo emblemático da vasocomunicação entre o nosso sistema romano-germânico e o sistema da common law.

O lapso de tempo que ocorre entre o nascimento da obrigação e o adimplemento, que anteriormente consubstanciava um vazio prestacional, passa a ser preenchido por deveres instrumentais, que obrigam as partes a sempre adotarem um comportamento que corresponda a determinado standard-conduta, estabelecido pelos princípios da boa-fé objetiva e da confiança.

Colocando-se voluntariamente o devedor em posição contrária ao cumprimento útil da obrigação principal, estar-se-á diante de um procedimento violador do dever de correção, do dever de lealdade, do dever de honestidade, de proteção da pessoa ou patrimônio da contraparte, e do dever de colaboração com esta para o alcance dos fins perseguidos pelo contrato.

À luz da doutrina da obrigação como processo, pode asseverar-se que qualquer conduta do devedor que destrua a presunção de que o contrato existe para que as partes se entreguem reciprocamente, de forma útil, às respectivas prestações, viola um vínculo que é fruto da confiança, violação que acontece mesmo antes do momento de adimplemento formalmente previsto, porque a relação obrigacional consiste em um processo contínuo, sem vazios temporais.

Esse comportamento do devedor, transgredindo deveres acessórios, antes do momento do adimplemento da prestação principal, não deixa de ser uma infringência do dever genérico de coerência, significando um venire contra factum proprium.

A jurisprudência já se manifestou aderente ao princípio do inadimplemento contratual antecipado. É emblemático o aresto, de 1983, do Tribunal de Justiça do Rio Grande do Sul, cuja ementa é a seguinte: 
Contrato de participação, assegurando benefícios vinculados à construção de hospital, com compromisso de completa e gratuita assistência médico-hospitalar. O Centro Médico Hospitalar de Porto Alegre Ltda. não tomou a mínima providência para construir o prometido hospital e as promessas ficaram no plano das miragens: assim ofende todos os princípios de comutatividade contratual pretender que os subscritores de quotas estejam adstritos à integralização de tais quotas, sob pena de protesto dos títulos. Procedência da ação de rescisão de contrato em conta de participação. ${ }^{11}$

Veja-se, igualmente, o acórdão do Superior Tribunal de Justiça, com a seguinte ementa: "Promessa de compra e venda. Quebra antecipada de contrato. Evidenciado que a construtora não cumprirá o contrato, o promissário comprador pode pedir a extinção da avença e a devolução das importâncias que pagou. Recurso não conhecido." ${ }^{2}$ Ainda a seguinte decisão do Tribunal de Justiça do Rio de Janeiro: "Ação de rescisão de contrato c/c indenização por danos morais. Possibilidade de desistência do pacto ou sua rescisão." ${ }^{13}$

Neves (2009, p. 359) aborda a questão do inadimplemento antecipado:

Não é difícil imaginar a situação na qual o devedor atue de tal modo que o futuro adimplemento se impossibilite. Muitas vezes, antes mesmo do advento da data ajustada para o pagamento, as circunstâncias demonstram que o devedor não terá condições de cumprir com seu dever, por atitudes a ele atribuíveis, resultando num inadimplemento antecipado.

Refere o autor mencionado que antes da data ajustada o credor já tem plena certeza de que não haverá adimplemento. Trata-se de um adimplemento útil ao credor, tal como previsto no momento da criação da obrigação. Menciona ele ainda a Convenção de Viena, de 1980, que, no artigo 72.1, preceituou que "se antes da data do cumprimento for manifesto que uma parte cometerá uma violação do contrato, a outra parte poderá declarar a resolução deste", recentemente incorporada pelo Brasil através do Decreto no 8.327, de 16 de outubro de 2014. Assim, verifica-se que a doutrina do inadimplemento antecipado, importada do sistema da common law, foi inteiramente recepcionada entre nós.

Ocorre, como anota o autor em tela, a antecipação dos efeitos do inadimplemento, que poderão ser reclamados pelo credor desde logo. Invoca ele a lição de Aguiar Júnior (2004) e também Azulay (1997).

\section{BOA-FÉ OBJETIVA, ONEROSIDADE EXCESSIVA E LESÃO CONTRATUAIS}

Outro instituto que deve estar presente na decisão de manutenção de uma determinada avença, é o da onerosidade excessiva nos contratos, previsto nos arts. 478 a 480, do Código Civil brasileiro, caso não cumprido o

\footnotetext{
${ }^{11}$ BRASIL, Tribunal de Justiça do Estado do Rio Grande do Sul. Apelação Cível n ${ }^{5}$ 582000378. Centro Médico Hospitalar de Porto Alegre e Nilo Antonio Peruzzo. Relator: Desembargador Athos Gusmão Carneiro. Porto Alegre 8.02.1983) (internet, site cit.).

${ }^{12}$ BRASIL. Superior Tribunal de Justiça. 4a Turma. Recurso Especial. 30.09.626. Carvalho Hosken S/A Engenharia e Construções e Luciano Camilo de Souza. Relator: Ministro Ruy Rosado de Aguiar, 07.06.2001) (internet, site cit.).

${ }^{13}$ BRASIL. Tribunal de Justiça do Rio de Janeiro. 8a Câmara Cível. Apelação Cível 2005.001.19441. Macrob Assessoria ao Mercado Imobiliário Ltda. e Fabiola Maria Gaeria e outros. Relator Luiz Felipe Francisco. Rio de Janeiro, 13.09. 2005) (internet, site, cit.).
} 
dever de negociação com fairness pela outra parte, para recomposição equitativa das condições pactuadas, dever o qual é visto como acessório e decorrente da boa-fé objetiva.

Preceitua o art. 478 que:

Nos contratos de execução continuada ou diferida, se a prestação de uma das partes se tornar excessivamente onerosa, com extrema vantagem para a outra, em virtude de acontecimentos extraordinários e imprevisíveis, poderá o devedor pedir a resolução do contrato. Os efeitos da sentença que a decretar retroagirão à data da citação.

Como visto ocorre a onerosidade excessiva quando uma prestação de obrigação contratual, em razão de acontecimento extraordinário e imprevisível no momento da formação do contrato, se torna, no momento da execução, notadamente mais gravosa do que era quando do seu surgimento.

O sinalagma genético desaparece, superado pela gravosidade da prestação do devedor, quando confrontada com a contraprestação a ser feita pelo credor. Na realidade não se cuida de "dificuldade de adimplemento" (Messineo, 1997, p. 687), nem a onerosidade excessiva fica a meio caminho entre essa dificuldade de prestação e a impossibilidade de prestação.

A apuração da onerosidade excessiva se faz através da avaliação objetiva da prestação em si e por si, em confronto com a contraprestação.

A onerosidade excessiva pode ser concebida como uma recusa à entrega da prestação tal como prevista originariamente no contrato, em virtude da superveniência de um desequilíbrio entre dita prestação do devedor e a contraprestação incumbente ao credor. Contudo, a desproporção e o desequilíbrio entre as prestações, com implicações decorrentes da boa-fé objetiva, podem ser observados não apenas ante a onerosidade excessiva contratual em razão de acontecimentos supervenientes, extraordinários ou imprevisíveis, à relação estabelecida, mas também em razão de lesão contratual, cujo desequilíbrio ocorrido pode dar-se até mesmo nas negociações preliminares, ou seja antes mesmo da celebração da avença, referindo-se a situações jurídicas não paritárias, ou seja, em que esteja presente uma parte hipossuficiente.

É a hipótese versada pela teoria da lesão tal qual albergada hodiernamente pelo art. 157, caput e $\$ \$ 1^{\circ} \mathrm{e}$ 20, do Código Civil, ao prescrever que "Ocorre a lesão quando uma pessoa, sob premente necessidade, ou por inexperiência, se obriga a prestação manifestamente desproporcional ao valor da prestação oposta", bem como "Aprecia-se a desproporção das prestações segundo os valores vigentes ao tempo em que foi celebrado o negócio jurídico" e que "Não se decretará a anulação do negócio, se for oferecido suplemento suficiente, ou se a parte favorecida concordar com a redução do proveito".

O parágrafo primeiro desse dispositivo legal estabelece que a desproporção, o desequilíbrio a viciar a própria gênese, a própria concretização do contrato, deve ser surpreendido, de conseguinte, no próprio instante em que foi celebrado o negócio, com o vício ocorrendo na formação da vontade, e não na sua declaração (Nader, 2003), ao passo que o parágrafo segundo afasta a incidência dos efeitos decorrentes do reconhecimento concreto 
da lesão se a parte favorecida, agindo com a já mencionada fairness, oferecer suplemento suficiente ou concordar com a redução do proveito, assim havido por excessivamente oneroso ao contraente hipossuficiente.

Cumpre esclarecer que, antes do Código Civil de 2002, o ordenamento jurídico brasileiro já previa a lesão contratual por desequilíbrio entre as contrapartidas assumidas quando da celebração do contrato, a implicar desproporcional e excessiva onerosidade à parte em hipossuficiência, a qual caracteriza-se não apenas pela premente necessidade, ou por inexperiência, mas também por sua leviandade, segundo um lucro patrimonial que exceda o quinto do valor corrente ou justo da prestação feita ou prometida, imputando-se a tal conduta, se praticada de forma dolosa pelo beneficiário, o cometimento do crime de usura real, consoante o art. 40, "b", da Lei n. 1.521/51 (Lei dos Crimes contra a Economia Popular).

Tal conduta, considerada criminosa, é estendida aos "procuradores, mandatários ou mediadores que intervierem na operação usuária, bem como os cessionários de crédito usurário que, cientes de sua natureza ilícita, o fizerem valer em sucessiva transmissão ou execução judicial” ( $\operatorname{art.} 4^{\circ}, \mathbb{\$} 1^{\circ}$, da Lei n. 1.521/51), com os efeitos do seu reconhecimento sendo agravados pelas circunstâncias de sua prática se dar “... em época de grave crise econômica... ocasionar grave dano individual... dissimular-se a natureza usurária do contrato" ou "quando cometido... por militar, funcionário público, ministro de culto religioso; por pessoa cuja condição econômicosocial seja manifestamente superior à da vítima..." e "em detrimento de operário ou de agricultor; de menor de 18 (dezoito) anos ou de deficiente mental, interditado ou não” (art. 4º \2 2 I, II, III e IV, “a” e “b”, da Lei n. 1.521/51).

É importante realçar que, em linhas gerais, o Código Civil de 2002, no $\$ 2^{\circ}$ do art. 157, restabeleceu o antes previsto no art. $4^{\circ}, \mathbb{S} 3^{\circ}$, da Lei n. 1.521/51, revogado pela Medida Provisória no 2.172-32, de 2001, permitindo a manutenção do negócio jurídico entabulado, malgrado a gravidade da lesiva onerosidade excessiva imposta ao hipossuficiente, se a parte beneficiária, agindo de boa-fé, predisponha-se a compor o equilíbrio (e não recompor), instaurando-se a proporcionalidade antes inexistente entre as prestações.

Importante também esclarecer que a necessidade ou inexperiência da parte lesada não necessitam ser de conhecimento do beneficiado, não havendo que se falar ou verificar a ocorrência de dolo ou da má-fé deste, vez que a lesão é, em verdade, efluente de sua mera ciência ao realizar um negócio cujo lucro mostra-se anormal (Tepedino; Barboza, e Moraes, 2004) juntamente com a condição de hipossuficiência da outra parte (Pereira, 1997).

A apuração da desproporção entre as prestações no ajuste, nessa hipótese de lesão contratual, se faz diferentemente da modalidade de onerosidade excessiva verificada nas contratações paritárias - através de avaliação objetiva e subjetiva da prestação, em confronto não só com a contraprestação, mas também com as circunstâncias que caracterizam a parte lesada hipossuficiente. 
Verifica-se, assim, que a função de controle defluente da boa-fé objetiva, ao coibir o exercício desequilibrado de direitos subjetivos (exercício abusivo de direitos), obsta a tutela de certas pretensões, vez que excessivamente onerosas ou lesivas a uma das partes contratantes, afastando manifesta desproporção por vantagens demasiadas em sacrifício aos interesses legítimos da outra parte.

\section{BOA-FÉ OBJETIVA ADMINISTRATIVA, CAUSA E SUA ACEPÇÃO PACTUAL CONCERTADA}

Postos os principais aspectos da boa-fé objetiva quanto à sua contemporânea acepção em sentido mais lato no dito novo Direito Contratual, inclusive sob um viés de Direito Comparado, cumpre, na sequência, proceder-se à contextualização de sua dimensão publicista.

Adentrando-se na seara do Direito Administrativo, ante a perspectiva do processo de positivação das políticas públicas através do exercício das competências político-administrativas atribuídas aos diversos atores sociais que as detêm, a teoria da boa-fé objetiva administrativa, malgrado revele-se aplicada sob sua função vetorial-interpretativa em torno da ideia geral de colaboração ao longo da execução dos contratos administrativos (e, por isso, sob um prisma, assim, macroscópico e dinâmico), verifica-se vocacionada às próprias ações estruturais destes, aos próprios atos de sua concretização e que neles culminam (pactos públicos estes vistos enquanto espécie de negócio jurídico), pois relacionada a dois dos seus elementos, aos seus quê (conteúdo) e ao como (forma) (Caldas, 2014b).

Diferencia-se, assim, da teria da causa que, não obstante também introduza o mesmo vetor, ou seja, mesma diretriz interpretativa concertada de cooperação e colaboração, aplica-se à relação jurídica pactual pública pelo viés funcional do porquê (motivação - vista como o terceiro elemento dos ajustes públicos), segundo o mesmo prisma, isto é, ao longo de todo o processo de execução e em suas diferentes fases (Caldas, 2014b).

Em tal diapasão, assevera Couto e Silva (2011, p. 34) que "O princípio da boa-fé contribui para determinar o que e o como da prestação e, ao relacionar ambos os figurantes do vínculo, fixa, também, os limites da prestação. Já Figueiredo Nery (2011, p. 34 e 61) entende que

A causa constitui um elemento valorativo funcional (...). Quando se abre espaço à priorização da vertente funcional do contrato, a causa passa a ser elemento chave, tanto para munir outros institutos de um paradigma interpretativo (...). A vocação constitucional da atividade administrativa exige essa vinculação entre todos os momentos contratuais, ou seja, entre a causa do contrato e sua execução.

Diante de tal tessitura, reforçando o entendimento anterior, pode-se afirmar que

a causa (dita, ainda, razão por Emílio Betti, 2008) do contrato administrativo, também comportando uma visão estática, orgânica, corpórea (de ato administrativo lato sensu), é igualmente vista como o seu porquê (motivação), embora aí identificada com seu núcleo funcional, traduzido na síntese dos efeitos jurídicos concretizadores de políticas públicas (as quais encartam os interesses públicos de um determinado setor da vida pública), ou seja, 
com sua função socioeconômica (Betti, 2008), a consubstanciar-se em vetor hermenêutico incrementado pela coincidência do princípio da eficiência (faceta do primado da boa administração pública ${ }^{14}$, conforme ressalta Bandeira de Mello, 2011),... em torno da ideia de parceria (...), afirmada pela boa-fé objetiva administrativa, enquanto outro vetor interpretativo dos ajustes públicos, que sob esse prisma orgânico, estático, ligar-se-á aos seus outros elementos, quais sejam, a sua forma e o seu conteúdo, em expressão da moralidade administrativa em seu maior grau de concreção. (Caldas, 2014b, p. 363-364).

Em consonância a tal circunstância, inclusive, já se pronunciou a jurisprudência pátria:

(...).a Administração Pública não pode se apartar de seu sério compromisso com a moralidade administrativa, que é padrão constitucional de sentido ético, que não pede, mas impõe, a adoção de critérios pautados na mais séria lealdade e probidade. Entre as razões recursais foi invocado o princípio da "boa-fé objetiva", que é instrumento do Direito Civil, mas que guarda grande simetria com o principio da moralidade, marco orientador do Direito Público. A extrema proximidade entre os institutos do Direito favorece a compreensão e o entendimento, na medida em que são ordens vetorizadas ou impulsionadas por um conteúdo que ultrapassa o mero sentido formal da LEI, atingindo um compromisso com o sentido de justiça, que ingressa no campo jurídico, não só como padrão, que confere o melhor sentido às leis, mas como exigência que direciona a gestão pública. (grifo nosso) ${ }^{15}$

E na doutrina, extrai-se de Bandeira de Mello (2004, p. 81) que

A Administração Pública está sujeita a um dever de probidade - no que se inclui a lealdade perante os administrados. $\mathrm{O}$ dever de probidade administrativa não é apenas imposto pela Ética, mas está consagrado pelo texto constitucional, nos arts. 37 e 82, VI. Bem por isso, a Administração está jungida a se comportar de modo leal com os administrados. Em quaisquer de seus atos, o Estado - tanto mais porque cumpre a função de ordenador da vida social - tem de emergir como interlocutor sério, veraz, responsável, leal e obrigado aos ditames da boa-fé. De seu turno, os administrados podem agir fiados na seriedade, responsabilidade, lealdade e boa-fé do Poder Público, maiormente porque a situação dos particulares é, em larguíssima medida, condicionada por decisões estatais, ora genéricas, ora provenientes de atos administrativos concretos.

Decorre, ante tais noções, que

o estudo da 'vontade' administrativa nos chamados contratos administrativos ou de direito público ${ }^{16}$, inclusive quanto ao seu grau de discricionariedade à luz do primado da eficiência $^{17}$ (inserto que é no da boa administração pública), deve estar atrelado às modernas concepções de causa (enquanto função socioeconômica negocial) e processo,

\footnotetext{
${ }^{14}$ Previsto no art. 37 "caput”, Constituição Federal de 1988, e no art. 41, da Carta dos Direitos Fundamentais da União Europeia, cuja redação, proclamada em 07 (sete) de dezembro de 2000 e aprovada pelo Tratado de Lisboa (art. 6º), assim dispõe em seus itens "1" a "4": "1. Todas as pessoas têm direito a que os seus assuntos sejam tratados pelas instituições e órgãos da União de forma imparcial, equitativa e num prazo razoável. 2. Este direito compreende, nomeadamente: . o direito de qualquer pessoa a ser ouvida antes de a seu respeito ser tomada qualquer medida individual que a afecte desfavoravelmente, . o direito de qualquer pessoa a ter acesso aos processos que se the refiram, no respeito dos legítimos interesses da confidencialidade e do segredo profissional e comercial, . a obrigação, por parte da administração, de fundamentar as suas decisões. 3. Todas as pessoas têm direito à reparação, por parte da Comunidade, dos danos causados pelas suas instituições ou pelos seus agentes no exercício das respectivas funções, de acordo com os princípios gerais comuns às legislações dos Estados-Membros. 4. Todas as pessoas têm a possibilidade de se dirigir às instituições da União numa das línguas oficiais dos Tratados, devendo obter uma resposta na mesma língua”.

${ }^{15}$ BRASIL. Tribunal de Justiça do Estado de São Paulo. Relator: Venício Salles. Voto n. 5.394, Apelação Cível com Revisão no 0109997-40.2008.8.26.0000 (815.421-5/7-00), São Paulo; 12a Câmara Direito Público; v. u.; j. 15/10/2008; DOE: 30/10/08; Disponível em: https://esaj.tjsp.jus.br/cjsg/getArquivo. do?cdAcordao=3312445\&cdForo=0; Acesso em : 17/07/2014.

${ }^{16}$ Considerados, v. g., como de prestação de serviços e concessões de serviços públicos, precedidas ou não de obras públicas, inclusive sob a roupagem das parcerias público-privadas.

${ }^{17}$ Segundo o qual, dentre as várias opções legais possíveis, deve-se sempre escolher a melhor delas.
} vol. 08, nº. 04, Número Especial. Rio de Janeiro, 2015.pp. 2670-2695 
permitindo uma crítica desde as políticas públicas que lhe antecedem até depois do exaurimento da avença, prosseguindo, e. g., com os deveres secundários de fidelidade, sigilo (confidencialidade) ou auxilio instituídos em decorrência da boa-fé objetiva que lhe envolve, implicando perscrutação de acordo com as competências político-administrativas vigentes e seu respectivo grau de vinculação à avença pública enfocada, de sorte a, com isso, também se ter as formas mais consentâneas de controle institucional e social, à luz da cooperação e do consenso que hoje permeiam as ações estatais nas relações com os particulares. (Caldas, 2014b, p. 364)

Ainda na esteira de Sundfeld pode-se considerar que:

A vontade livre, aquela que significa exercício da liberdade, tem um canal de expressão básico: o indivíduo. A vontade funcional é canalizada em um processo, no qual o agente é apenas um dos elementos. Não houvesse processo para a formação da vontade funcional e ela seria idêntica à da vontade livre: centrada no agente. (Sundfeld, 1987, p. 61)

Nesse sentido, revela-se indubitavelmente relevante estudarem-se as omissões administrativas quando também relacionadas às ditas regulações e regulamentações das avenças públicas, como ainda suas repercussões em termos de validade das relações jurídicas assim estabelecidas (cuja "vontade" estatal é expressa pelo exercício de competência discricionária $)^{18}$, o que, todavia, aqui será apenas objeto de eventuais comentários incidentais, principalmente em razão do corte metodológico necessário para o cumprimento dos objetivos propostos neste artigo.

À guisa de exemplificação, essa matéria terá tratamento incidental ao mais abaixo se especificarem os atos convencionais administrativos e seus atores. Sobre essa questão relacionada à ausência de cláusula regulamentadora nos contratos administrativos, Figueiredo Nery (2011, p. 40) observa que:

(...) A adequação do regime de direito público às premissas do direito contratual exige que se explore ao máximo a consensualidade, isto é: na ausência de cláusula regulamentadora ou diante de controvérsia sobre sua aplicação, a interpretação deve ter como objeto imediato a análise à causa do contrato - produto da consensualidade -, e não prima facie a utilização de cláusulas exorbitantes.

O importante de se observar, nesse momento, é que as omissões administrativas que possam implicar invalidades por vício de "vontade" nos ajustes públicos, marcadamente em sua fase pré-negocial, são as que venham a permitir enriquecimentos ou decréscimos patrimoniais ilícitos, consoante indesejáveis interesses secundários (do Estado, em prol dos próprios agentes ou de terceiros) por si albergados em claro descompasso

\footnotetext{
${ }^{18}$ De conseguinte, é de extremo interesse o estudo da regulação e da regulamentação, e sua influência direta no desempenho e desenrolar das avenças administrativas com os particulares, principalmente à luz da tendência de maior repartição do risco da atividade administrativa com esse setor, quer quanto ao planejamento, quer quanto à própria execução (atividade, essa, hoje vista como primordialmente voltada à realização das obras e serviços de infraestrutura do Estado), sem contar sua forte imbricação com os temas do controle social e da participação popular, os quais têm ganhado grande fôlego, grande impulso nos últimos anos. Com efeito, tem-se como desdobramento do tema da regulação e regulamentação dos ajustes administrativos, enquanto instrumentos de concretização das políticas públicas, também o do princípio da boa administração pública, há muito estudado e hodiernamente bastante desenvolvido não só na Europa e Estados Unidos da América, como também no Brasil, em função da sua utilização como mecanismo de otimização e racionalização de uma atividade administrativa discricionária mais consentânea com os anseios e necessidades contemporâneos. Porém a crítica em tela não permite um enfoque aprofundado e detido da regulação e regulamentação como fatores de concretização da "vontade" administrativa, sendo que apenas se versará incidentalmente as omissões que tenham a si relação quando voltadas para as avenças públicas. Dessa maneira, o aprofundamento desse temário de estudo deverá ocorrer de forma apartada, em momento oportuno e posterior.
} vol. 08, nº. 04, Número Especial. Rio de Janeiro, 2015.pp. 2670-2695 
com os interesses públicos legalmente prioritários (e, assim, estampados em políticas públicas) e colimados pelos ajustes, vistos enquanto mecanismos de sua concreção (ditos government by policies).

Assim, não importa se a omissão ilícita e lesiva do agente público traz um específico querer seu em desatender a legislação aplicável à avença pública, mas, simplesmente, se a desatendeu de modo lesivo, pois “(...) o que vicia o ato em casos do gênero é o objetivo descompasso entre o ato e a finalidade da lei, e não meramente $o$ vício de vontade, pois o que importa não é se o agente quis ou não atender à lei, mas se a atendeu ou desatendeu." (Bandeira de Mello, 2004, nota de rodapé no 29, p. 399).

\section{BOA-FÉ OBJETIVA ADMINISTRATIVA E “VONTADE PÚBLICA” NOS CONTRATOS ADMINISTRATIVOS}

Nesse aspecto, surge o conceito, hoje desenvolvido pelo Direito português, do princípio da boa-fé objetiva administrativa ${ }^{19}$, a assegurar a vinculação dos critérios de ética e lealdade (além, obviamente, de boa-fé) às vontades "pública" e particular, impondo uma conduta sincera e honesta, sem qualquer astúcia ou malícia quando da observância aos ditames pactuais concertados, dialógicos, ou seja, em atenção à expectativa de parceria, de cooperação entre os polos contraentes, visando sempre a dar concreção às políticas públicas envolvidas no ajuste público, bem como à correlata conduta administrativa, enquanto sua finalidade última.

Seu conceito, tal qual positivado no direito lusitano corresponde à ideia de que "A Administração Pública e os particulares devem, nas suas relações, agir com boa-fé, respeitando, em especial, a confiança que possa ter sido criada pela sua atuação anterior" (Silveira, 1998, p. 17).

De certo modo, esse princípio da boa-fé objetiva administrativa não deixa de ser uma expressão do já consabido princípio da moralidade administrativa, alçado à condição de bem jurídico autonomamente tutelado por meio de ação popular (Caldas, 2014a), à luz do expressamente previsto no art. 5o, LXXIII, da Constituição Federal de 1988, agregando-se a ele a ideia do consenso, da cooperação, da colaboração entre os particulares e a Administração, em maior flexibilização das avenças públicas a serem desenvolvidas em parceria (Garbi, 2012).

Nesse diapasão, inclusive à luz do art. 54, caput, da Lei no 8.666/93, onde determina-se que aos contratos administrativos aplicam-se, supletivamente, os princípios da teoria geral dos contratos e as disposições de direito privado, revelam-se pertinentes as lições de Couto e Silva (2011) sobre a boa-fé, ao tê-la enquanto um

\footnotetext{
${ }^{19}$ Sua previsão se mostra expressa no ordenamento jurídico português, tanto pelo disposto no art. $266-2$ da Constituição da República (2. Os órgãos e agentes administrativos estão subordinados à Constituição e à lei e devem actuar, no exercício das suas funções, com respeito pelos princípios da igualdade, da proporcionalidade, da justiça, da imparcialidade e da boa-fé), como pelo art. 60-A, "1" e "2", do seu Código de Procedimento Administrativo (No exercício da actividade administrativa e em todas as suas formas e fases, a Administração Pública e os particulares devem agir e relacionar-se segundo as regras da boa fé. 2 - No cumprimento do disposto nos números anteriores, devem ponderar-se os valores fundamentais do direito, relevantes em face das situações consideradas, e, em especial: a) A confiança suscitada na contraparte pela actuação em causa; b) O objectivo a alcançar com a actuação empreendida).
} 
mandamento fundamental de direito, com aplicação e vigência independentemente de sua expressa previsão legal. Dessa maneira, consoante explica, mostra-se como um princípio geral das obrigações, a ser observado em todas as relações jurídicas sinalagmáticas ${ }^{20}$.

O autor explica, ainda, que tal princípio da boa-fé, com significado de regra de conduta, de consideração, abarca todos os que participam do vínculo obrigacional, estabelecendo um elo de cooperação em torno de um fim objetivo por eles divisado, contribuindo, dessa maneira, para a fixação dos limites da prestação de cada um.

Relaciona-se, portanto, à lealdade, à lisura, à correção e retidão do proceder por parte dos contraentes e o respeito à esfera jurídica recíproca e também de outrem, ao introduzir deveres adicionais (também ditos secundários, anexos ou instrumentais, consistentes na consideração que se necessita ter para com o outro), possivelmente dissociados da vontade das partes - malgrado não se manifestem em todas as situações concretamente verificadas - uma vez que não podem ser considerados como genéricos e despersonalizados tal como a correção social (Couto e Silva, 2011). Tal objetividade da boa-fé decorre, assim, da especificação da pessoa a quem se deve a consideração e também da determinação da relação obrigacional estabelecida com esta pessoa (Couto e Silva, 2011).

O fato de o princípio da boa-fé objetiva ${ }^{21}$ estabelecer deveres ditos adicionais, secundários (meramente acessórios ou com prestação autônoma), fiduciários, anexos, laterais, instrumentais aos expressos na avença e que estes possivelmente independem da vontade das partes, em si, é a característica primordial para sua aplicabilidade, de forma supletiva e com fundamento, repita-se, no art. 54, caput, da Lei no 8.666/93 (Meirelles, 2006), aos contratos administrativos - pois neles, a "vontade pública" é a legalmente estipulada - inclusive servindo como um vetor interpretativo integrador (Couto e Silva, 2011) para atendimento da função consensual das cláusulas expressas e implícitas avençadas, verificado em conjunto com o outro vetor hermenêutico, a causa, cuja teoria é igualmente empregue no exame de suas fases.

Nesse sentido é a doutrina de Aguiar Júnior (2012, p. 190) onde afirma-se que:

\footnotetext{
${ }^{20}$ À luz da teoria geral dos contratos, tem-se como princípios fundamentais de Direito Contratual, a autonomia da vontade, o consensualismo, a obrigatoriedade e a relatividade das convenções, além da boa-fé. Mais remotamente, a boa-fé foi introduzida no ordenamento jurídico pátrio por intermédio do art. 131, do Código Comercial de 1850. A seu turno, o Código Civil de 1916 fez menção a si, como se verifica, e. g., nos arts. 490 e 514, ao versar a posse e o possuidor de boa-fé. Também o Código de Defesa do Consumidor revela disposições reguladoras da boa-fé nas relações de consumo, consoante os arts. 4ㅇ, III, e 51, IV, enquanto princípio de política nacional das relações de consumo e como norma de conduta contratual, respectivamente. Hodiernamente, porém, há previsão expressa da boa-fé objetiva em dispositivos como o art. 113 (nele tida por norte à interpretação dos negócios jurídicos) e o art.187, c/c art. 927, caput (em que vista como critério de identificação do ato ilícito, implicando obrigação de reparação dos danos dele decorrentes), além de especificamente para os contratos, consoante disposto no art. 422, todos da Lei nº 10.406/02 (Código Civil de 2002), sendo neste havida por verdadeira cláusula geral, de conteúdo propositalmente vago, a implicar aplicação estatal dirigida, ou seja, mediante intervenção estatal na economia do negócio jurídico contratual, inclusive aos contratos administrativos, por força, repita-se, do previsto no art. 54, caput, da Lei no 8.666/93.

${ }^{21}$ Como já dito mais acima, a boa-fé objetiva revela-se sob três distintas funções, quais sejam, de vetor interpretativo-integrador, de ensejador de deveres jurídicos e de controlador, limitador ao exercício de direitos subjetivos (implicando supressio ou surrectio, conforme o caso concreto).
} 


\begin{abstract}
A boa-fé objetiva é hoje a cláusula geral mais lembrada para a solução dos litígios sobre relações privadas. Embora presente no âmbito do direito público, uma vez que sua posição de supremacia influencia também a ação administrativa, especialmente nos contratos, é no âmbito do direito civil - na parte do direito obrigacional - que essa ideia-força tem sido utilizada com regular frequência pelos tribunais em suas três principais funções: criar deveres secundários ou anexos, embora não previstos na lei ou no contrato; impor limites à ação das partes, embora permitida pela lei ou pelo contrato, pois os direitos subjetivos somente podem ser exercidos no limite autorizado pela boa-fé; e auxiliar na interpretação das cláusulas contratadas.
\end{abstract}

Cabe observar que a atividade integrativa da lei pela Administração Pública se dá mediante o emprego do raciocínio por analogia, quando da solução de questões a si entregues (de pleitos resultantes em processos administrativos), ou por meio do exercício de competência discricionária.

A integração por analogia, segundo Valle Figueiredo (2008) devidamente fundamentada nos ensinamentos de Juan Francisco Linares, é possível no Direito Administrativo e deve existir nos casos de leis de individuação estreita (insuficiente), faltante ou incompleta, ante a explicitação de norma ou normas jurídicas preexistentes e expressas, utilizando-se, como diretriz desse raciocínio, de princípio ou princípios gerais do Direito aplicáveis ao caso (dentre os quais, o da boa-fé), com a ressalva de que essa integração não implique imposições ou sanções.

Já a integração por meio do exercício de competência discricionária consiste, basicamente, na atividade administrativa segundo a qual o Administrador, ao tomar uma decisão para um caso concreto, deve escolher a melhor (princípio da eficiência) dentre as várias legalmente possíveis, à luz dos critérios de conveniência e oportunidade.

Postos tais contornos da boa-fé objetiva administrativa, e sua aplicabilidade ao regime jurídico de direito público nos pactos com o Estado, é mister salientar que por ser conceito de cunho dinâmico (a exemplo do da causa), a plena identificação das suas qualidades, dos seus aspectos, é impossível, restando apenas viabilizada a verificação do seu campo de incidência em comparação ao da autonomia da vontade, bem como do seu grau de intensidade quanto aos deveres que enseja, cuja medida é dada pelo fim do negócio jurídico a que se relaciona, isto é, in concreto (Couto e Silva, 2011).

E tal verificação se dá a partir do fato de que a prestação principal do negócio jurídico é determinada, é comandada pela finalidade que - no caso do contrato administrativo - é finalidade pública, fim público, observado a partir de manifestação ou declaração de vontade juridicizada, podendo, ainda, existirem decorrentes deveres secundários (adicionais, anexos, instrumentais), dependentes e independentes. Os independentes surgem desvinculados da finalidade pública principal (apenas ligados aos deveres principais pela origem, pelo nascimento), de sorte a poderem até perdurar após o adimplemento da obrigação principal, com vida própria (como os deveres de auxílio quando da fase de recebimento do objeto - e os respectivos equipamentos - por parte da Administração Pública). Já os dependentes, surgem vinculados, presos ao núcleo do negócio jurídico de 
origem, possuindo "autonomia relativa", pois não continuam após o adimplemento principal e nem são acionáveis de modo autônomo.

Tais deveres, quer principais, quer secundários (ditos ainda adicionais, anexos ou instrumentais), dependentes ou independentes, decorrem tanto da vontade, como do princípio da boa-fé e da proteção jurídica dos interesses, conforme a situação concretamente considerada. Há, porém, casos em que o conteúdo do negócio jurídico resulta diretamente da boa-fé, enquanto que, em outros, o conteúdo contratual se configura a partir de uma fusão de vontade e boa-fé (Couto e Silva, 2011).

Daí a constatação de que os deveres instrumentais (inclusive implícitos) nos contratos administrativos, em si, implica um fator de balizamento às ditas cláusulas exorbitantes (em regra também implícitas) e regulamentares pelo viés da moralidade administrativa, cuja boa-fé objetiva administrativa ressai como sua expressão direta na relação jurídica administrativa concretamente considerada.

Nesse contexto, é mister observar-se que o conceito da boa-fé objetiva administrativa tem sua valia por se apresentar como um parâmetro de conduta para o Estado quanto ao modus operandi público dentro das circunstâncias globalmente consideradas e motivadas, atenuando-se os excessos intervencionistas (externados, nos contratos administrativos, pelas cláusulas exorbitantes e regulamentares) e seus efeitos sistêmicos maléficos ${ }^{22}$, como também em relação ao conteúdo do seu arranjo com os agentes privados internos, absolutamente indispensáveis para a criação e o desenvolvimento da infraestrutura e economia nacionais.

\section{CONCLUSÕES}

As competências político-administrativas se traduzem em políticas públicas, vistas como metas de governo devidamente positivadas, fruto de um planejamento participativo (concertado) por excelência encontrado, em grau de maior abstração do Direito pátrio, no PPA - Plano Plurianual (quadrienal), na LDO - Lei de Diretrizes Orçamentárias e na LOA - Lei Orçamentária Anual (ânuas), sendo neles circumpostas em planos, programas e projetos sociais de origem, por óbvio, constitucional.

A necessária concreção em contratos administrativos dessas competências político-administrativas, expressadas em políticas públicas governamentais, dá-se por intermédio do dito processo de positivação, em uma conexidade instrumental com a contínua relação de causalidade (também dita de imputação), em fluxo cujo contraplano fático-social corresponde ao das relações jurídicas, in casu, administrativas.

Sob essa óptica dinâmico-processual da relação jurídica pactual pública, a boa-fé objetiva administrativa desponta incidindo não apenas na fase de execução dos contratos administrativos, mas, igualmente, nas suas fases pré (de planejamento e licitatória) e pós-contratuais (em que se tem o recebimento do objeto pela Administração,

${ }^{22}$ A respeito de tais efeitos sistêmicos indesejáveis, vide Caldas (2010). vol. 08, nº. 04, Número Especial. Rio de Janeiro, 2015.pp. 2670-2695 
e. g.), impondo condutas concertadas (de consenso, cooperação, colaboração e parceria) segundo a tripla função de servir como canon interpretativo-integrativo, ser considerada como norma de criação de deveres jurídicos instrumentais e, ainda, utilizar-se como norma de controle e limitação ao exercício de direitos subjetivos inclusive implicando a responsabilização de seu descumprimento, enquanto maior concreção do princípio da moralidade administrativa, por culpas in contrahendo e post factum finitum.

A boa-fé objetiva administrativa, assim, introduz vetores interpretativos concertados, não apenas no sentido participativo da intrínseca parceria, cooperação e colaboração entre o Estado, os particulares contratados e as demais partes envolvidas, mas segundo uma visão dinâmico-processual de seus elementos, tais sejam, motivação, conteúdo e forma, buscando estabelecer os aspectos pactuais públicos funcionais (socioeconômicos) e estruturais.

Os deveres instrumentais decorrentes da boa-fé objetiva administrativa, existentes ao lado da prestação principal componente do vínculo obrigacional público, informam a correção não apenas do comportamento dos contratantes (Estado e particulares), como igualmente a dos reguladores (institucionais e autônomos) e dos seus beneficiários (usuários), nas fases pré-contratual (interna - pré-edital, mais hodiernamente dita de planejamento - e externa - licitatória), contratual e pós-contratual, ressaltando e realçando o espírito ético e leal de cooperação e parceria ao longo de todo o processo em favor da consecução e realização útil da prestação principal, atendidas as necessidades (públicas) e expectativas da população beneficiária das obras e serviços públicos (fim público).

Por fim, a função limitadora e de controle defluente da boa-fé objetiva administrativa, coíbe o exercício desequilibrado tanto de direitos subjetivos dos particulares, como de prerrogativas da Administração, obstando a tutela de condutas abusivas, inclusive administrativas, que tornem a relação jurídica pactual pública desequilibrada ou desproporcional, sob o ponto de vista econômico-financeiro, e, de conseguinte, excessivamente onerosa ou lesiva.

\title{
THE ADMINISTRATIVE OBJECTIVE GOOD FAITH AND INTERPRETATION OF ADMINISTRATIVE CONTRACTS: THE IMPLEMENTATION OF PUBLIC FUNCTION
}

\begin{abstract}
This article aims to analyze the application of the principle of objective good faith in government contracts in its consensual aspect in order to delimit the purpose and scope of an interpretation focused on the fulfillment of contractual obligations, nailed on trust and loyalty. Also seeks to determine to what extent the duties resulting from the objective good faith being (re)interpreted to meet the different contractual stages, even reaching the aspects that can subjacer to the culpa in contrahendo, culpa post factum finitum, the principle nemo potest venire contra factum proprium and the anticipated contractual default. The analysis of objective good faith can be
\end{abstract}


performed also from the finding of excessive burden and injury of contractual obligations considered to be related to this principle, thereby defining an interpretive vector that results in undoing or contract maintenance, to be examined. Regarding the methodology applied, it adopted the inductive method for establishing the conceptual assumptions and practices of the principle of objective good faith within the framework of a reinvigorated interpretation by the agreement as a structural foundation of popular participation and social control, anchored on the principle of due procedural process of law at administrative legal relationships.

Keywords: Objective Good Faith; Contractual Duties; Government Contracts; Public Function; Popular Participation; Social Control.

\section{REFERENCIAS}

AGUIAR JÚNIOR, Ruy Rosado de. Extinção dos Contratos por Incumprimento do Devedor. Resolução. $2^{a}$ ed.. Rio de Janeiro: Aide, 2004.

O Código Civil de 2002 e a jurisprudência do STJ em matéria obrigacional. In: Temas relevantes do direito civil contemporâneo: reflexões sobre os 10 anos do Código Civil. LOTUFO, Renan; NANNI, Giovanni Ettore; MARTINS, Fernando Rodrigues (Coord.). São Paulo: Atlas, 2012, p. 189-201.

A boa-fé nas relações de consumo. Revista de Direito do Consumidor, vol. 14, n. 20, São Paulo, abr./jun 1995, p. 377-388.

ALARCÃO, Rui de. Direito das Obrigações. Coimbra: Ed. policopiada, 1983.

AZEVEDO, Antonio Junqueira. Insuficiências, deficiências e desatualização do projeto de Código Civil na questão da boa-fé objetiva. Revista dos Tribunais, vol. 89, n 775 , São Paulo : Editora Revista dos Tribunais, mai 2000, p. 11-17.

AZULAY, Fortunato. Do Inadimplemento Antecipado do Contrato. Rio de Janeiro: Brasília, 1977.

BANDEIRA DE MELLO, Celso Antônio. Curso de direito administrativo. São Paulo: Malheiros Editores, $28^{\mathrm{a}}$ ed., 2011.

A estabilidade dos atos administrativos. Revista trimestral de direito público, no 48, Malheiros Editores, out./dez. de 2004, p. 77-83.

BETTI, Emilio. Teoria geral do negócio jurídico. Campinas: Servanda Editora, 2008.

BRASIL. Tribunal de Justiça do Estado de São Paulo. Relator: Venício Salles. Voto n. 5.394, Apelação Cível com Revisão no 0109997-40.2008.8.26.0000 (815.421-5/7-00), São Paulo; 12a Câmara Direito Público; v. u.; j. 15/10/2008; DOE: 30/10/08; Disponível em: <https://esaj.tjsp.jus.br/cjsg/getArquivo.do?cdAcordao $=3312445 \& \mathrm{cdForo}=0>$; Acesso em: 17/07/2015.

CALDAS, Roberto Correia da Silva Gomes. O contexto sinérgico das atividades de regulação administrativa concertada à luz dos denominados contratos administrativos. Interesse Público. ano 12, no 61, Belo Horizonte : Editora Fórum, maio/junho de 2010, p. 69-82.

Direito de ação popular: requisitos especiais, eficiência, eficácia, efetividade e controle social. RECHTD -

Revista de Estudos Constitucionais, Hermenêutica e Teoria do Direito, v. 6, nº 3, out-dez/2014a, p. 288-297. 
Contrato administrativo concertado, causa e boa-fé: maior eficiência e eficácia à luz das teorias dos atos separáveis e da incorporação. Revista Opinião Jurídica. Fortaleza : Unichristus, v. 12, n. 16, jan-dez/2014b, p. 357371.

CALDAS, Roberto Correia da Silva Gomes; DIZ, Jamile Bergamaschini Mata. A responsabilidade do Estado nos contratos administrativos por culpa in contrahendo e post factum finitum: por uma interpretação dinâmica da relação negocial. RECHTD - Revista de Estudos Constitucionais, Hermenêutica e Teoria do Direito, v. 7, no 3 , out-dez/2015 (no prelo).

CASTRO NEVES, José Roberto de. Direito das Obrigações. Rio de Janeiro: G/Z Editora, 2009.

CORDEIRO, Antonio Menezes. Da Boa-fé no Direito Civil. Lisboa: Almedina, 2007.

COUTO E SILVA, Clóvis V. do. A obrigação como processo. Rio de Janeiro : Editora FGV, 1a ed., 5a reimpressão, 2011.

São Paulo : José Bushatsky Editor, 1976.

EBKE, Werner F.; STEINHAUER, Bettina M. The Doctrine of Good Faith in German Contract Law. In: Good Faith and Fault in Contract Law. Oxford: Edited by Jack Beatson and Daniel Friedman, 1997, p. 171-190.

FIGUEIREDO, Lucia Valle. Curso de direito administrativo. 9a. Ed. São Paulo: Malheiros Editores, 2008.

FONSECA, Rodrigo Garcia da. A função social do contrato e o alcance do artigo 421 do Código Civil. Rio de Janeiro: Renovar, 2007.

GARBI, Carlos Alberto. A flexibilização do princípio da integridade da prestação e a possibilidade do parcelamento da dívida. Temas relevantes do direito civil contemporâneo: reflexões sobre os 10 anos do Código Civil. LOTUFO, Renan; NANNI, Giovanni Ettore; MARTINS, Fernando Rodrigues (Coord.). São Paulo: Atlas, 2012, p. 218-252.

GOMES, Orlando. O princípio da boa-fé no Código Civil português. Revista da Divisão Jurídica do Instituto do Açúcar e do Álcool. Separata, Ano XVII, vol. 17, n 116, Rio de Janeiro : Instituto do Açúcar e do Álcool - Divisão Jurídica, jan./mar. 1972, p. 171-177.

Contratos. Rio de Janeiro : Forense, $12^{a}$ edição, 1991.

MARQUES, Claudia Lima. Contratos no Código de Defesa do Consumidor. São Paulo: Editora Revista dos Tribunais, $3^{\mathrm{a}}$ ed., 1999.

MARTINS-COSTA, Judith. A Boa-Fé no Direito Privado. São Paulo: Revista dos Tribunais, 1999.

MESSINEO, Francesco. Manuale di Diritto Civile e Commerciale, vol. 3. Giuffrè, 1959.

NADER, Paulo. Curso de direito civil - volume 1: parte geral. Rio de Janeiro : Forense, 2003.

NEGREIROS, Teresa. Teoria do contrato - novos paradigmas. 2ª ed. Rio de Janeiro: Renovar, 2006.

NERY, Ana Rita de Figueiredo. A causa do contrato administrativo: análise do conteúdo contratual como parâmetro de aplicação do princípio da eficiência. Rio de Janeiro: Lumen Júris Editora, 2011. 
NONATO, Orozimbo; AZEVEDO, Philadelpho; GUIMARÃES, Hahnemann. Ante-projeto de código de obrigaçôes: parte geral. Rio de Janeiro, Imprensa Nacional, 1943.

PEREIRA, Caio Mário da Silva. Lesão nos contratos. 7ª ed. Rio de Janeiro: Forense, 1997.

PEREIRA, Regis Fichtner. A reponsabilidade civil pré-contratual. Rio de Janeiro: Renovar, 2001.

SCHREIBER, Anderson. Proibição de Comportamento Contraditório - Tutela da Confiança e Venire Contra Factum Proprium. Renovar: Rio de Janeiro, 2005.

SILVA, Jorge Cesa Ferreira da. A boa-fé e a violação positiva do contrato. Rio de Janeiro : Renovar, 2002.

SILVA, Agathe E. Schmidt da. Cláusula geral de boa-fé nos contratos de consumo. Revista de Direito do Consumidor, São Paulo, n. 17, jan./mar. 1996, p.159-160.

SILVEIRA, Luís Lingnau. Código do procedimento administrativo. Lisboa: Gráfica Jesus Ltda, 1998.

SUNDFELD, Carlos Ari. A importância do procedimento administrativo. Revista de direito público, no 84, São Paulo : Editora Revista dos Tribunais, out./dez. de 1987, p. 64-74.

TEPEDINO, Gustavo. Notas sobre os princípios contratuais, e a relatividade dos contratos. Revista de Direito Renovar, n46, Rio de Janeiro: Renovar, jan./abr. 2015, p. 41-51.

TEPEDINO, Gustavo; BARBOZA, Heloisa Helena; MORAES, Maria Celina Bodin de (coord.). Código Civil interpretado conforme a Constituição da República. Rio de Janeiro: Renovar, 2004

TEPEDINO, Gustavo; SCHREIBER, Anderson. A boa-fé objetiva no Código de Defesa do Consumidor e no Novo Código Civil. In: Obrigações - estudos na perspectiva civil-constitucional. TEPEDINO, Gustavo (Coord.). Rio de Janeiro: Renovar, 2005, p. 29-44.

WIEACKER, Franz. El Principio General de la Buena-Fé. Imprenta: Madrid, Civitas, 1977.

Trabalho enviado em 19 de janeiro de 2016.

Aceito em 29 de janeiro de 2016. 